\title{
The Oxy-Fuel Combustion Power Plant Model with Desulphurization Process and The Effect of Different Types of Coal on Operating Parameters
}

\author{
Oğuzhan Erbaş ${ }^{1 *}$, Halit Arat ${ }^{2}$ \\ 1* Kutahya Dumlupinar University, Faculty of Engineering, Department of Mechanical Engineering, Kutahya, Turkey, (ORCID: 0000-0001-9424-4273), \\ oguzhan.erbas@dpu.edu.tr \\ 2 Kutahya Dumlupinar University, Faculty of Engineering, Department of Mechanical Engineering, Kutahya, Turkey, (ORCID: 0000-0002-6634-2535), \\ halit.arat@dpu.edu.tr
}

(First received 24 May 2021 and in final form 5 August 2021)

(DOI: $10.31590 /$ ejosat.942155)

ATIF/REFERENCE: Erbas, O. \& Arat, H. (2021). The Oxy-Fuel Combustion Power Plant Model with Desulphurization Process and The Effect of Different Types of Coal on Operating Parameters. European Journal of Science and Technology, (25), 636-643.

\begin{abstract}
Clean coal technologies are defined as applications that improve environmental acceptability and efficiency in producing, preparing and using coal. With clean coal technologies, it is possible to increase the amount of energy obtained per unit ton by reducing emissions and wastes. However, today there are strict sanctions that must be followed due to the legal regulations on the protection of the environment and combating climate change. At this point, the clean coal-burning technologies in which the oxy-fuel combustion process (with the possibility of $\mathrm{CO}_{2}$ storage) takes place come to the fore. In this study, the method of burning fuel with oxygen in a thermal power plant with a gross electricity generation of $500 \mathrm{MW}$ was discussed. This thermal power plant model also has a fluidized bed dryer, a desulphurization plant, and a $\mathrm{CO}_{2}$ storage process. The combustion results of different properties of coals were examined, and their effect on operating parameters was investigated.
\end{abstract}

Keywords: Clean coal, Desulphurization, Oxy-Fuel, Combustion, Fluidized bed dryer.

\section{Kükürt Giderme Prosesli Oksi-Yakıt Yanmalı Enerji Santrali Modeli ve Farklı Kömür Tiplerinin İşletme Parametrelerine Etkisi}

$\ddot{O} \mathbf{z}$

Temiz kömür teknolojileri, kömürün üretimi, hazırlanması ve kullanımında çevresel kabul edilebilirliği ve verimliliği artıran uygulamalar olarak tanımlanmaktadır. Temiz kömür teknolojileri ile emisyon ve atıkları azaltarak birim ton başına elde edilecek enerji miktarını artırmak mümkündür. Bununla birlikte, günümüzde çevrenin korunması ve iklim değişikliğiyle mücadeleye ilişkin yasal düzenlemelerin bir sonucu olarak uyulması zorunlu katı yaptırımlar mevcuttur. Bu noktada özellikle oksi-yakıt yanma işleminin $\left(\mathrm{CO}_{2}\right.$ depolama imkânı ile) yer aldığı "temiz kömür yakma teknolojileri" ön plana çıkmaktadır. Bu çalışmada, brüt elektrik üretimi $500 \mathrm{MW}$ olan bir termik santralde oksijen ile yakıt yakma yöntemi ele alınmıştır. Bu termik santral modelinde ayrıca bir akışkan yataklı kurutucu, bir desülfürizasyon tesisi ve bir $\mathrm{CO}_{2}$ depolama prosesi bulunmaktadır. Farklı özellikteki kömürlerin yanma sonuçları incelenmiş ve işletme parametrelerine olan etkileri araştırılmıştır.

Anahtar Kelimeler: Temiz kömür, Kükürt giderme, Oksi-Yakıt, Yanma, Akışkan yataklı kurutucu.

\footnotetext{
*Corresponding Author: oguzhan.erbas@dpu.edu.tr
} 


\section{Introduction}

Energy is one of the essential factors for developing countries, which directly affects the welfare of society. It has improved social and economic issues by providing a safe, adequate, affordable, and clean energy supply for countries. Therefore, as in the past, the efforts of countries to access energy resources and ensure supply security are increasingly continuing. In this context, especially coal, as typical in domestic energy sources, is one of the primary energy resources (TUBA-EWG, 2018). Although there is intense debate over the impact of coal on the environment, coal is an indispensable resource in energy production. Coal is still the most widely used source of electricity generation in many developed countries. It is expected to maintain this leading position in the future.

In meeting the growing energy needs for our country, it is crucial to increase our domestic lignites for electricity generation and heating and industry. Because; this situation will contribute to the economy and energy security (reducing external dependence). Energy imports share a significant share in our country's current account deficit. Therefore, there is a need to increase the use of lignite from our domestic resources by reducing environmental disadvantages within the framework of a holistic, realistic, and sustainable strategy. There are strict sanctions of the legal regulations on Environmental Protection and combating climate change (Erbas and Rahim, 2009).

A large amount of $\mathrm{SO}_{2}$ can be released due to combustion since coal contains a high amount of sulfur in its structure. Sulfur is a toxic gas that is seriously harmful to human health and the environment. Therefore, it is necessary to reduce $\mathrm{SO}_{2}$ at its source before releasing it into the atmosphere (Acar et al., 2018). Low-quality coals are used by passing through certain stages to minimize environmental damage and because they are not suitable for direct use (Açıkkar and Sivrikaya, 2020). Since coals in our country are generally lignite coal with low calorific value, their evaluation for electricity generation purposes is more appropriate. The calorific values of our coals vary from 1000 $\mathrm{kcal} / \mathrm{kg}$ to $4200 \mathrm{kcal} / \mathrm{kg}$. The lower calorific value of about $90 \%$ is less than $3000 \mathrm{kcal} / \mathrm{kg}$. Clean coal technologies are essential for our low-quality domestic coal to be burned efficiently and without damaging the environment in energy production. Clean coal technologies are defined as "technologies designed to increase coal combustion efficiency and minimize environmental impacts". Clean coal technologies are a family of environmentally superior technological innovations compared to today's conventional technologies (ICCTS, 2017). The combustion in a circulating fluidized bed, biomass-coal mixed combustion process, oxy-fuel combustion process, and plasma method combustion-gasification processes are examples of the leading clean coal technologies. The first step of clean coal technologies is to ensure coal is produced from the mine as clean as possible. For this purpose, the coal washing (enrichment) facilities are established, although not all coals are suitable for these operations.

Oxy-fuel combustion is considered one of the best carbon dioxide emission retention methods and storage in coal-fired power plants (Gopan et al., 2015). This technology is similar to a conventional coal-fired power plant regarding the steam cycle and power equipment. The main difference lies in the comburent used during the combustion in the boiler. Precisely, it consists of a mixture of oxygen and recirculated flue gas. As a result of this

e-ISSN: 2148-2683 process, the flue gas stream shows a concentration of $\mathrm{CO}_{2}$ of around $70 \%$ wt. After water separation, the $\mathrm{CO}_{2}$ stream is compressed and further purified in the Compression and Purification Unit $(C P U)$ before storage or use (Portillo et al., 2021). Xiong et al. (2011) analyzed the operating parameters of an 800 MW power plant under oxygenated combustion conditions. They found a $10.36 \%$ reduction in net efficiency due to the inclusion of $A S U$ (air separation unit) and $C P U$ in the system under oxy-fuel combustion conditions (Xiong et al., 2011). In these systems, it is possible to reduce the energy cost of $\mathrm{CO}_{2}$ compression work and obtain more energy from highpressure flue gas with the help of pressurized oxy-fuel combustion (Pang et al., 2020). Skorek-Osikowska et al. (2013) conducted a supercritical power plant thermodynamic analysis (460 MW). They have examined the system's power consumption under oxy-fuel combustion conditions (SkorekOsikowska et al., 2013). The usage of waste heat from $A S U$ and flue gas treatment systems significantly reduced the power consumption of $A S U$ and $C P U$ during the process. Gopan et al. (2020) have proposed a gradual pressurized oxy-fuel combustion process. While they aimed to eliminate flue gas recirculation, they were also able to increase the net efficiency of the energy conversion plant by about $6 \%$. They have also found that the increase in fuel humidity affected system efficiency under pressure operation (Gopan et al., 2020). Yan et al. (2015) have compared three modes of flue gas recirculation: dry, semi-dry, and wet in the supercritical oxy-fuel combustion power cycle. They found that the optimized semi-dry process showed the highest efficiency and ease of operation. They also increased net efficiency by one percentage point by heating feed water (Yan et al., 2015). Pang et al. (2020), oxy-fuel burning experiments were carried out by burning lignite and anthracite coals in a fluidized bed burner $(30 \mathrm{~kW})$. The high combustion pressure has improved the oxy-fuel combustion efficiency of both lignite and anthracite. This increase in combustion efficiency was higher for the anthracite coal type (Pang et al., 2020). Moon et al. (2019) have examined the combustion properties of oxy-fuel combustion and air combustion processes in the circulating fluidized bed. They compared the carbon dioxide purity and emission amounts in the resulting flue gas. In the experiments, semi-bituminous coal and lignite coal in different proportions were used as fuel. As a result of this research, the oxy-fuel database, combustion properties, temperature and pressure profiles, solid suspension density, and $\mathrm{CO}_{2}$ purity, including emissions and combustion efficiency, were created. According to the results, it was observed that high $\mathrm{CO}_{2}$ concentration reduces the load of the $\mathrm{CO}_{2}$ purification unit, keeping pressure drop to a minimum in the circulating fluidized bed increases combustion efficiency, and flue gas feedback significantly reduces emissions (Moon et al., 2019).

In this study, the method of burning fuel with oxygen in a thermal power plant with a gross electricity generation of 500 MW was discussed. This model is designed with the "EBSILON Professional" energy systems design program. The modeled thermal power plant includes a fluidized bed dryer, air separation unit, desulphurization unit, and $\mathrm{CO}_{2}$ compression process. Also, the system operating values were analyzed for coals with different characteristic properties.

\section{Material and Method}

Greenhouse gas emission values and national commitments on this issue (The Paris Climate Agreement) are seen as the two main problems that our country has to solve in energy. To reduce 
greenhouse gas emissions from fossil fuel-based energy production, first, turn to renewable energy sources and use technology that will reduce emission values in fossil fuel-based energy production plants. In addition, instead of imported resources, it is aimed at domestic resources in investment. Our lignites, which have a high reserve ratio in our domestic resources and have a low thermal value, should be evaluated with clean coal technologies. In this context, energy conversion systems with oxy-fuel combustion processes are seen as an alternative.

Oxy-fuel combustion technology is, in principle, a technology with flexibility that can be used in electricity generation and applied for every fuel. The central units that distinguish these systems from traditional combustion systems are $A S U$, flue gas return, and $\mathrm{CO}_{2}$ separation/storage units. In addition, the conventional combustion systems that are still working can also be converted into oxy-fuel combustion systems. In other words, oxy-fuel combustion systems can be retrofit integrated into existing systems (TUBA-EWG, 2018). Oxy-fuel combustion technology is seen as an efficient technology for coal combustion systems. When oxygen is used instead of air as combustion gas, carbon dioxide-rich flue gas flow occurs in the oxy-combustion plant. Combustion occurs through oxygen-enriched air, pure oxygen, or flue gas by returning to the reactor. The returned flue gas is also used to adjust the temperature in the burner.

The use of oxygen or oxygen-enriched air instead of air is based on the destruction of nitrogen, high in volume in the air, from the combustion gas. Carbon dioxide at high concentrations (80-90\% on a dry basis) can be efficiently and economically recovered by carbon dioxide compression. When oxygen is used as combustion gas, the combustion characteristic of the fuel changes significantly (Zheng, 2011). In addition, some equipment is required in oxy-fuel combustion plants. These are air separation units for oxygen production and flue gas compression units to purify and transport carbon dioxide. As part of this study, a thermal power plant that produces electricity with an oxy-fuel combustion process was also considered. The thermal power plant considered is modeled with the "EBSILON Professional" energy systems design program. The modeled thermal power plant structure is shown in Figure 1.

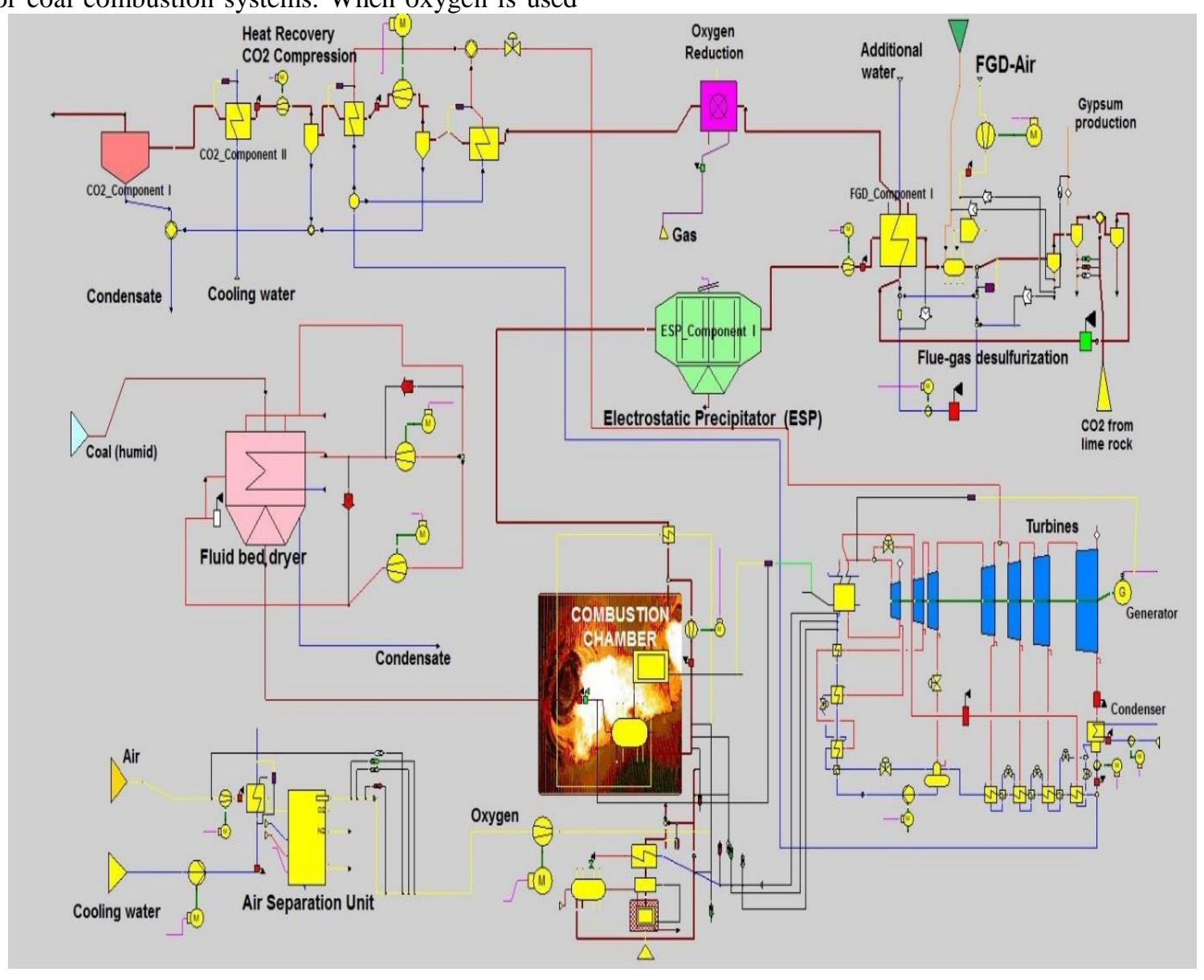

Figure 1. Schematic flow diagram of oxy-fuel combustion power plant model.

The analyzed system, coal drying unit (fluid bed dryer), air separation unit $(A S U)$, boiler, electrostatic parser (ESP), flue gas desulfurization $(F G D)$, and the purification of carbon dioxidecompression turbine-generator-condenser units covers. Part of the combustion gas is fed back again, mixed with oxygen, and sent to the burner. ESP is used to separate the dust from the flue gas, and the $F G D$ unit is used to remove the remaining sulfur oxides $\left(\mathrm{SO}_{\mathrm{x}}\right)$ in the flue gas. The flue gas then passes through the carbon dioxide purification and compression unit for water removal and compression. After finishing, the resulting flue gas can now be easily transported and injected into the storage area (White and et al., 2009). The variation of operating parameters in this analyzed oxy-fired thermal power plant model for different quality coals is shown in Table 1. 
Table 1. Power plant operating parameters for different quality coal.

\begin{tabular}{c|c|c|c|c|c|c}
\hline $\mathbf{N C V}(\mathbf{k c a l} / \mathbf{k g})$ & $\mathbf{P}_{\text {elknet }}(\mathbf{M W})$ & $\mathbf{M}_{\text {coal }}(\mathbf{t} / \mathbf{h})$ & $\mathbf{M}_{\mathbf{0}_{\mathbf{2}}}\left(\mathbf{m}^{\mathbf{3}} / \mathbf{h}\right)$ & $\boldsymbol{\beta}_{\mathbf{C O}_{\mathbf{2}} \mathbf{c o m p}} \mathbf{( \% )}$ & $\mathbf{M}_{\mathbf{C o}_{\mathbf{2}} \text { compoutlet }}(\mathbf{k g} / \mathbf{s})$ & $\mathbf{M}_{\mathbf{0}_{\mathbf{2}} \text { reduction(FGo) }}(\mathbf{k g} / \mathbf{s})$ \\
\hline 5348 (I) & 311.5 & 12.50 & 216450 & 94.8 & 101 & 122 \\
\hline 1941 (II) & 299.7 & 31.70 & 225968 & 95.6 & 114 & 137 \\
\hline 2454 (III) & 305.8 & 24.80 & 219469 & 94.9 & 108 & 130 \\
\hline 3708 (IV) & 306.3 & 17.50 & 218036 & 92.5 & 105 & 128 \\
\hline 4113 (V) & 306.8 & 16.10 & 219876 & 94.1 & 109 & 129 \\
\hline
\end{tabular}

\section{Results and Discussion}

It shows that the component that causes the most damage to exergy in energy conversion systems is the boiler system, depending on the nature of the combustion process. In general, this damage is increasing in coal-fired thermal power plants (Arslan and Erbas, 2021). In oxy-combustion, coal is burned with a mixture of $\mathrm{O}_{2} / \mathrm{CO}_{2}$ instead of air. For this, the flue gases are returned at specific rates, mixed with $\mathrm{O}_{2}$, and fed into the combustion chamber. The $\mathrm{CO}_{2}$ ratio in the resulting flue gases can be up to $90 \%$ and above. This, in turn, is the separation of $\mathrm{CO}_{2}$ in flue gases, and it allows it to be held. The results for five different types of coal were examined in the thermal power plant model with the oxy-fuel combustion process. The results were also analyzed, especially for the best and worst quality coals. The characteristic properties (elemental analysis values) of these coals used in the model are given in Figure 2.

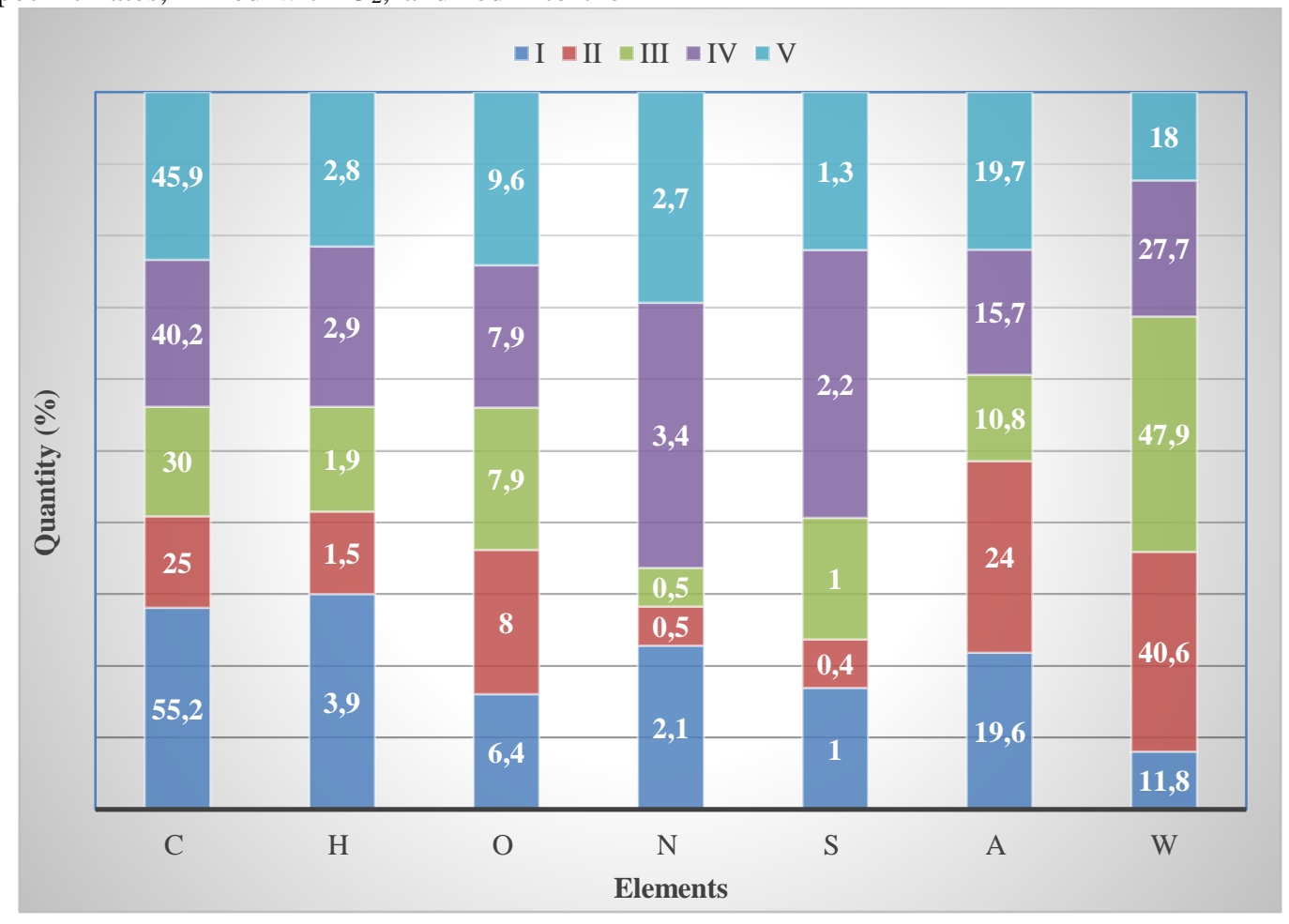

Figure 2. Elemental analysis values of different coal types used in the model.

Moisture in the structure of coal is one of the most critical parameters in terms of the chemical and physical properties of coal and the use of coal. As the degree of coalification decreases, the amount of moisture in the coal increases, and the structure of some young coals consists mainly of water. Coal drying technologies are gaining importance in terms of increasing combustion efficiency. Water can affect coal reactivity, gasification mechanisms, drying and volatile matter output, ignition temperature, tendency to crumble, transport economy, accumulation properties, limits of combustion. In addition, the effect of the moisture content of coal on combustion depends directly on the combustion system used.
Fluidized bed dryers with intense turbulence conditions provide an ideal dehumidification environment for coal fuels with high humidity. In the fluidized bed, the air pressurized through the fan passes through the dispensing nozzles, fluidizing the medium in which the grains are located. As a result, air passes through the solid particles that need to be fluidized at a high enough speed to defeat the gravitational force acting on the particles, ensuring that these particles are suspended. In the fluidized bed dryer, the thermal value of coal and the amount of energy spent according to the moisture content of the coal are shown in Figure 3. As the humidity increases and the thermal value of the fuel decreases, the amount of energy spent increases. 


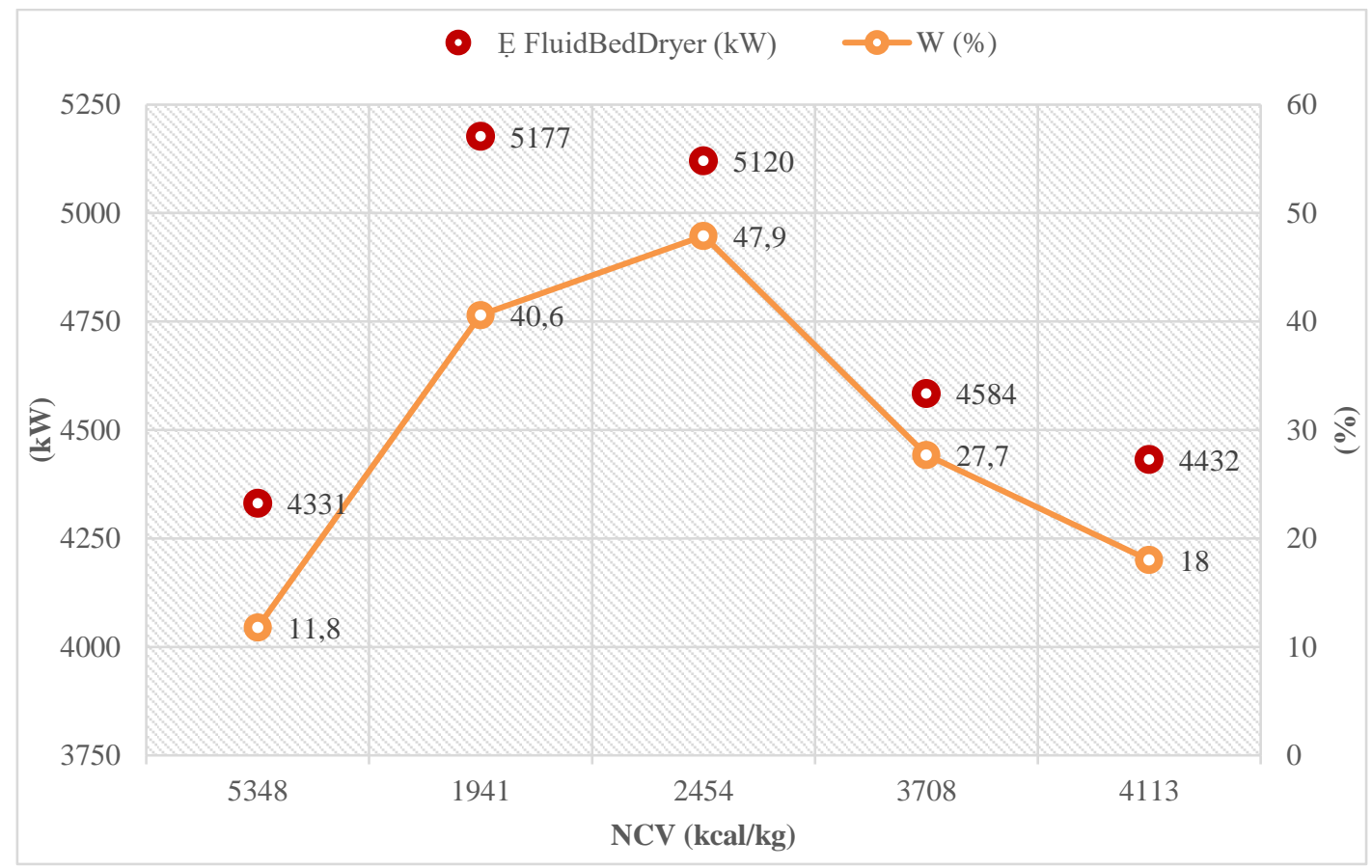

Figure 3. Effect of fuel thermal value and humidity on the amount of energy consumed.

The $A S U$, one of the most critical units of the system, provides the oxygen needed for combustion by decomposing air. The capacity of this unit varies depending on the need of the combustion system. This high-purity oxygen is mixed with recycled flue gas inside the boiler to ensure similar combustion conditions with air-burning systems before combustion. Mass flow values in the $A S U$ process for the "coal I" type are shown in Figure 4. Mixing with flue gas is very important so that existing building materials can withstand the high temperatures caused by combustion when working with pure oxygen.

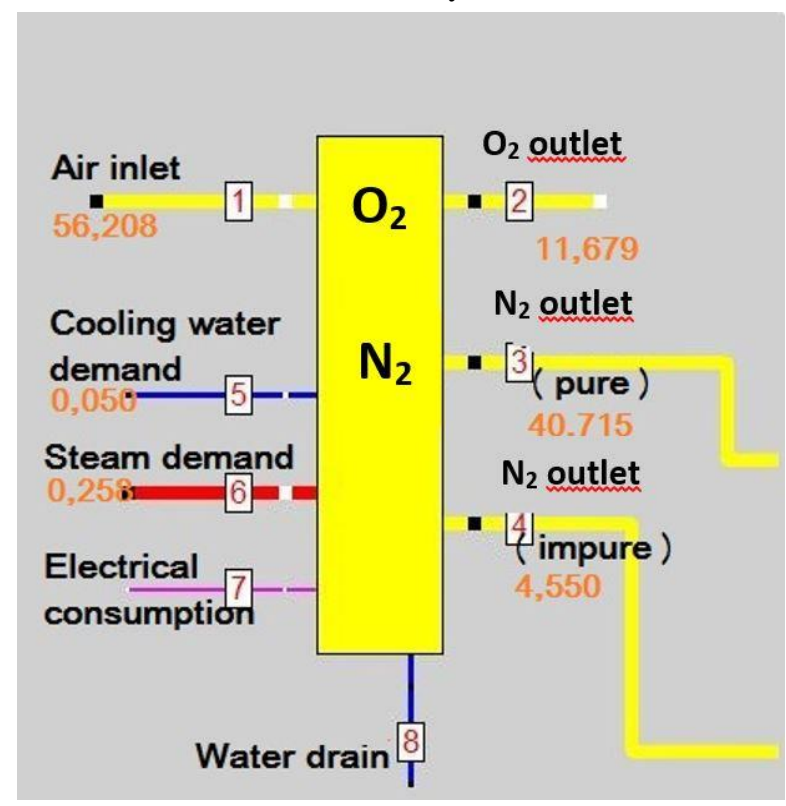

Figure 4. The mass flow values $\left(\mathrm{m}^{3} / \mathrm{s}\right)$ in the ASU.

The FGD technology is one of the most important technologies used to control $\mathrm{SO}_{2}$. The limestone process used as a separator in this technology has made it preferable to other techniques in terms of cost. The limestone reaction is similar to the lime reaction. Only the preparation stages and the liquid/gas ratios required for washing vary. Because limestone is less active than lime, a greater liquid/gas ratio is necessary for washing in limestone reactions. Considering the results of the $F G D$ process in the analyzed model, the amount of flue gas increases as the fuel thermal value decreases and the number of moisture increases. This situation causes an increase in the amount of solution and energy expended for the $F G D$ process. Calcium sulfate $\left(\mathrm{CaSO}_{4}\right)$ obtained in the $F G D$ process is more easily separated due to its large crystal structure. In addition, gypsum can be used in the production of materials such as cement. Because calcium sulfate is easily filtered, the accumulation in the wet filter inner surfaces and plumbing is much less. For the best (coal I) and worst (coal II) coal types, the changes in mass, temperature, and energy in the $F G D$ process are shown in Figure 5 . 


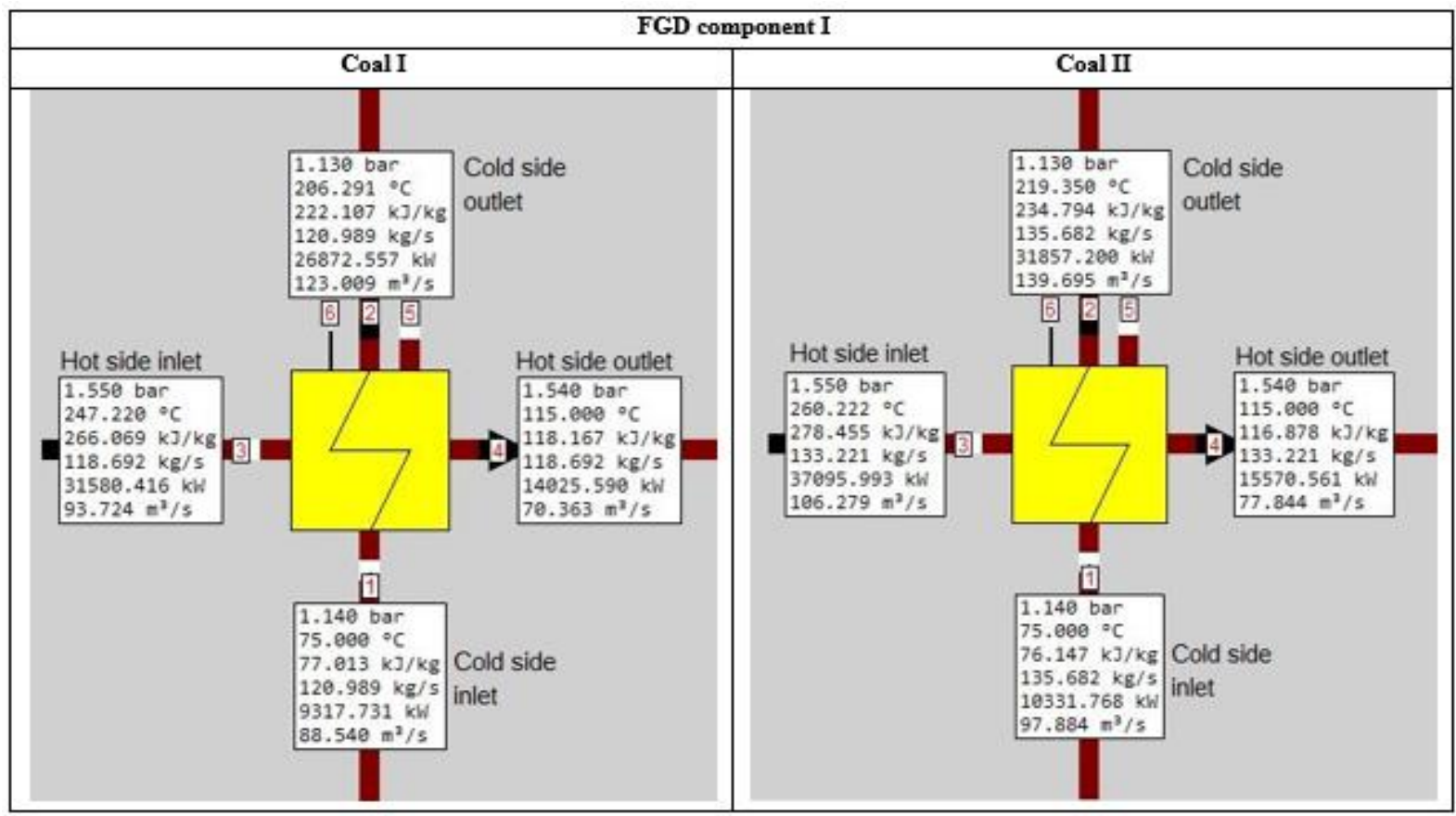

Figure 5. The mass and energy balance in the flue gas desulfurization (component I) system.

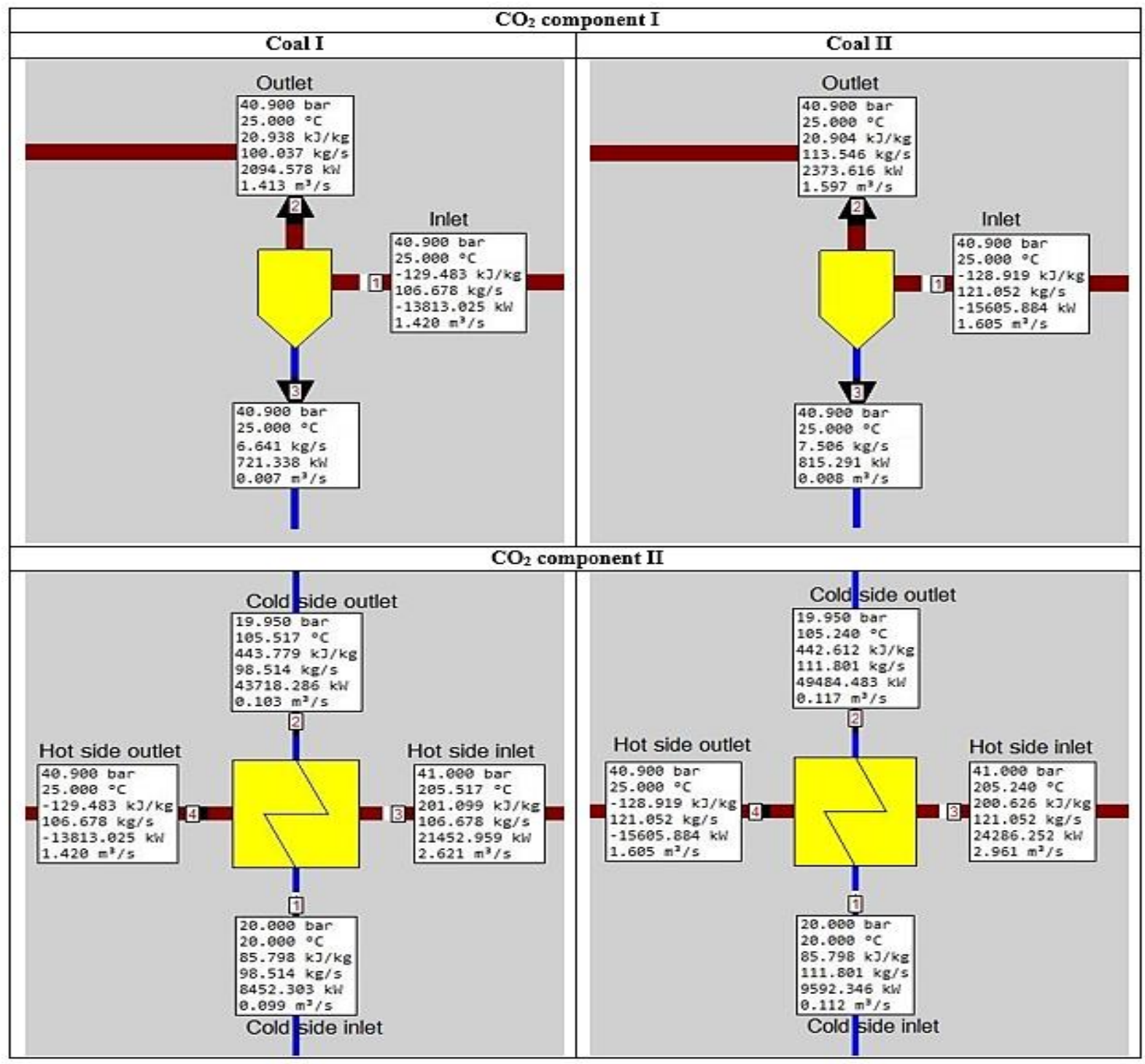

Figure 6. The mass and energy balance values of $\mathrm{CO}_{2}$ compression/storage unit. 
In clean coal technologies, the aim is to eliminate harmful coal emissions and ensure that carbon dioxide generated by combustion is stored in various forms (Y1lmazoglu, 2010). The most crucial difference between oxy-combustion systems and traditional systems is that the $\mathrm{CO}_{2}$ ratio in flue gases is very high $(65-95 \%)$. Thus, the separation and retention of $\mathrm{CO}_{2}$ are possible. The $\mathrm{CO}_{2}$ separation unit consists of a series of multistage compression and cooling steps. Here, first, the water is removed, and then the $\mathrm{CO}_{2}$ is liquefied. Non-liquefied gases ( $\mathrm{Ar}$, $\mathrm{N}_{2}, \mathrm{O}_{2}, \mathrm{CO}, \mathrm{NO}_{\mathrm{x}}$ ) are ejected from the chimney as exhaust gas. The $\mathrm{CO}_{2}$ ratio in flue gas can be significantly affected by air leaks in the system (TUBA-EWG, 2018). In addition, the proportion of $\mathrm{CO}_{2}$ increases as the ratio of $\mathrm{O}_{2}$ fed into the combustion chamber increases. The mass and energy balances in components I and II of the $\mathrm{CO}_{2}$ compression/storage unit are given in Figure 6.

The ESP is the most widely used technology in thermal power plants. The basic working principle of electrostatic filters is that the dust particles in the gas passing through the filter are charged with a high-voltage corona electrode. The particles are collected on this electrode, moving towards the collection electrode. The two most essential elements of the electrostatic filter are the corona and the collection electrodes (Kim et al., 2010).

The structure of the corona electrode and the corona discharge it creates significantly affect the electrostatic filter efficiency. The best performance in an electrostatic filter is generally possible with the appropriate selection of filter parameters and geometry at the initial stage. As the voltage applied to the corona electrode increases, the electrostatic filter efficiency also increases. Electrons separated from the electrode collide with gas molecules, ionizing them and creating new electrons.

The electrons that have formed hit the particles and stick. The particles poured from electrostatic filter electrodes resulting from shaking are collected, deposited, or discarded in hoppers. The performance of any electrostatic filter depends on the maximum electric field between the corona and the collecting electrode. Damages and changes in the mechanical integrity of the system cause a significant decrease in collection efficiency. The mass and energy balance values of the electrostatic precipitator unit are shown in Figure 7.

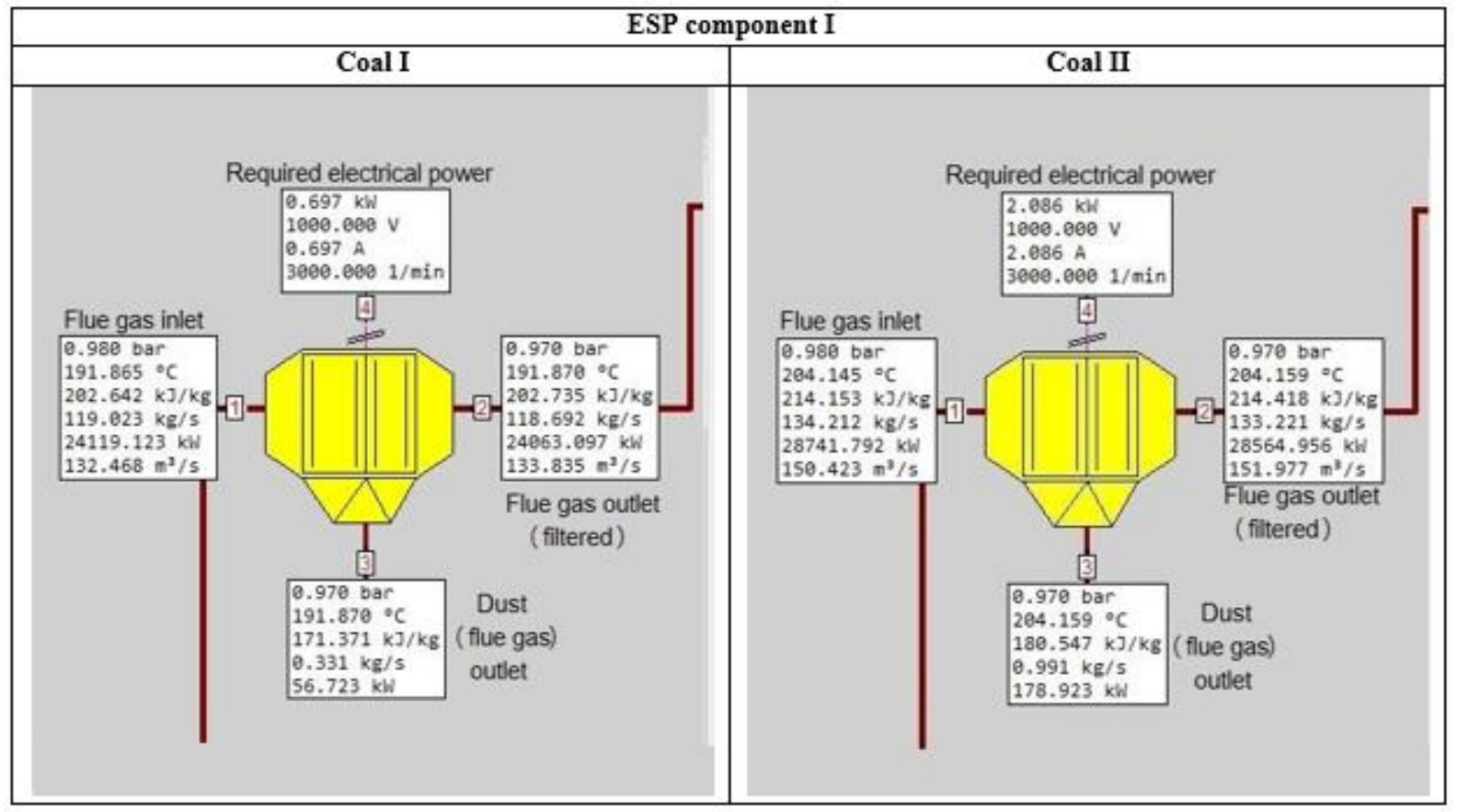

Figure 7. The mass and energy balance values of the ESP unit.

\section{Conclusions and Recommendations}

The coals owned by our country are mainly lignites with high ash, moisture, and sulfur rates and low thermal values. Most of the coal produced is burned at low yields in existing old power plants, creating environmental problems. Mainly based on the equipment and technologies of power plants, the most effective way to increase net efficiency at the desired rates are heat and process integration. A lot of recent work has focused on integrating heat recovery and atmospheric oxy-fuel combustion power plants. The optimization of system integration under different working conditions is also mandatory. With clean coal technologies, it is possible the reducing emissions and waste from coal usage and increasing energy to be obtained per unit ton. Thus, more energy can be produced using less coal. In this context, it is necessary to develop clean coal technologies according to the characterization of our existing coals and increase pilot-scale design-implementation studies. For this purpose, the oxy-fuel combustion plant model (coal-fired) was considered. In model outputs, net electricity generated for coal with the lowest thermal value (type II) was 299.7 MW. In comparison, net electricity generated for coal with the highest thermal value (type I) was 311.5 MW. In addition, coal consumption was $31.70(\mathrm{t} / \mathrm{h})$ and $12.5(\mathrm{t} / \mathrm{h})$.

\section{References}

Acar M. Ş., Kayapınar O. \& Arslan O. (2018) Islak kireçli baca gazı desülfürüzasyon sistemi termodinamik ve ekonomik analizi, Politeknik Dergisi, 21(2): 359-368. 
Açıkkar, M., \& Sivrikaya, O. (2020). Yıkanmış Türk Linyit Kömürlerinin Üst Isıl Değerinin Destek Vektör Regresyonu ile Tahmini. Avrupa Bilim ve Teknoloji Dergisi, (18), 16-24.

Arslan, O., \& Erbas, O. (2021). Investigation on the improvement of the combustion process through hybrid dewatering and air pre-heating process: A case study for a 150 MW coal-fired boiler. Journal of the Taiwan Institute of Chemical Engineers, 121, 229-240.

Erbas, O., \& Rahim, M. A. (2009) Düşük Kaliteli Linyitlerin Ultra Süper Kritik Kazanlarda Yakıt Olarak Kullanılması. Dumlupınar Üniversitesi Fen Bilimleri Enstitüsü Dergisi, (018), 83-90.

Gopan, A., Kumfer, B. M., \& Axelbaum, R. L. (2015). Effect of operating pressure and fuel moisture on net plant efficiency of a staged, pressurized oxy-combustion power plant. International Journal of Greenhouse Gas Control, 39, 390-396.

Gopan, A., Verma, P., Yang, Z., \& Axelbaum, R. L. (2020). Quantitative analysis of the impact of flue gas recirculation on the efficiency of oxy-coal power plants. International Journal of Greenhouse Gas Control, 95, 102936.

ICCTS (International Clean Coal Technologies Summit) (2017, May 18-19), Summit results report. Istanbul, Turkey.

Kim, J. H., Lee, H. S., Kim, H. H., \& Ogata, A. (2010). Electrospray with electrostatic precipitator enhances fine particles collection efficiency. Journal of Electrostatics, 68(4), 305-310.

Moon, J. H., Jo, S. H., Park, S. J., Khoi, N. H., Seo, M. W., Ra, H. W., ... \& Mun, T. Y. (2019). Carbon dioxide purity and combustion characteristics of oxy firing compared to air firing in a pilot-scale circulating fluidized bed. Energy, 166, 183-192.

Pang, L., Shao, Y., Zhong, W., Gong, Z., \& Liu, H. (2020). Experimental study of NOx emissions in a $30 \mathrm{kWth}$ pressurized oxy-coal fluidized bed combustor. Energy, 194, 116756.

Portillo, E., Fernández, L. M. G., Vega, F., Alonso-Fariñas, B., \& Navarrete, B. (2021). Oxygen transport membrane unit applied to oxy-combustion coal power plants: A thermodynamic assessment. Journal of Environmental Chemical Engineering, 9(4), 105266.

Skorek-Osikowska, A., Bartela, L., Kotowicz, J., \& Job, M. (2013). Thermodynamic and economic analysis of the different variants of a coal-fired, $460 \mathrm{MW}$ power plant using oxy-combustion technology. Energy Conversion and management, 76, 109-120.

TUBA-EWG (Energy Working Group) (2018), Clean coal technologies report (in Turkish). Turkish Academy of Sciences Publications.

Xiong, J., Zhao, H., Chen, M., \& Zheng, C. (2011). Simulation study of an 800 MWe oxy-combustion pulverized-coal-fired power plant. Energy \& Fuels, 25(5), 2405-2415.

White, V., Torrente-Murciano, L., Sturgeon, D., \& Chadwick, D. (2009). Purification of oxy-fuel-derived CO2. Energy Procedia, 1(1), 399-406.

Yan, K., Wu, X., Hoadley, A., Xu, X., Zhang, J., \& Zhang, L. (2015). Sensitivity analysis of oxy-fuel power plant system. Energy Conversion and Management, 98, 138-150.

Y1lmazoglu, M. Z. (2010). Pre-Combustion Carbondioxide Capture in Integrated Gasification Combined Cycles. Pamukkale Üniversitesi Mühendislik Bilimleri Dergisi; Cilt: 16 Sayı: 2; 173-179.
Zheng, L. (Ed.). (2011). Oxy-fuel combustion for power generation and carbon dioxide (CO2) capture. Elsevier Woodhead Publishing Limited, Philadelphia,17-31. 